\title{
REFLECTIONS ON THE BEGINNINGS OF LINGUISTICS AT TRIBHUVAN UNIVERSITY
}

\author{
Austin Hale
}

The definitive account of the birth and development of linguistics, and of the study of minority languages in Nepal has yet to be written. In this brief account we focus on the part of that development that arose from interactions between SIL and Tribhuvan University in the late 1960's and early 1970's.

The most outstanding memory I have from those early days is of the interest shown in linguistics by scholars in Nepal. Dr. Trailokya Nath Uprety (who was registrar at the time, and later, Vice Chancellor) was a key person in this regard. $\mathrm{He}$ was aware of the interest that foreign scholars had in the languages spoken in Nepal. Even though the official government stance at that time was to focus on Nepali as the only significant local language spoken in Nepal, these foreign scholars knew that many other languages were spoken here which were highly significant from a linguistic perspective, not only Indo-Aryan languages but Tibeto-Burman and Dravidian as well.

Though Dr. Uprety was aware of this interest, he was handicapped in providing assistance to these scholars by the fact that in those early days the University had no department devoted to such studies.

\section{The Agreement with Tribhuvan University}

My experience of the beginnings of linguistics at Tribhuvan University was from the vantage point of the beginnings of SIL in Nepal. These two beginnings were intertwined in a way that makes it difficult for me to write of one without the other. The research that SIL was involved in became a window through which university scholars could explore the discipline of linguistics, a long process that started in the late 1960 's and culminated with the formation of the Department of Linguistics in the mid-1990's.

On December 22, 1966 two representatives from SIL, Dick Pittman and Jim Dean, met with Dr. Uprety. He felt that before long Nepali would be the only language spoken in Nepal, and was keen to document the other languages before they disappeared. A three-year agreement was signed with SIL. What T.U. wanted was published papers to prove SIL's competence and its serious intent to describe the languages of Nepal. The contract was for three teams for three years, together with a fourth team for administration. During those three years each team needed to become functional in the national language, to do the language survey necessary to identify a suitable language, and to produce a substantial linguistic paper on that language. Unless there was significant publication before the end of 1968, the contract would not be renewed.

From our perspective, SIL's early years in Nepal were turbulent. In mid-1967 SIL lost the only member with advanced linguistic training that it had, leaving the teams without consultant help. In May 1968, Dr. Uprety called in Warren Glover who was director at the time. The first half of the three-year contract had elapsed, and SIL still had not published anything.

Hales arrived on the $1^{\text {st }}$ of June 1968 . The teams worked together well and manuscripts of four linguistic papers were submitted to Dr. Uprety in September 1968. They were published as a Special Linguistic Number of the Tribhuvan University Journal in September 1969.

\section{Some Key People -- Early Signs of Interest in Linguistics}

The most outstanding recollection that I have, following the renewal of the agreement with Tribhuvan University was of the highly gifted, deeply motivated university scholars that we were privileged to work with.

By the time we arrived, work on Conversational Nepali, the language learning course that SIL was writing, was well under way. We greatly appreciated the help of Chura Mani Bandhu over the next few months in checking the manuscript

Nepalese Linguistics, vol. 34, 2019, pp. 87-89. 
as it was typed. In the early days, my work with university scholars was done to a large extent in individual sessions. I was privileged to have many such sessions with Bandhu over the years, focusing initially on phonology.

In late May, 1971, we had a series of daily consultant sessions on Bantawa phonology in which Bandhu ended up serving as the consultant. Not only did Bandhu go on to earn the Ph.D. in linguistics, he was elected President of the Linguistic Society of Nepal in 1982. It should also be noted that Bandhu was the Chair of the task force for the establishment of the Central Department of Linguistics in the mid- '90's.

On the $12^{\text {th }}$ of February, 1969, a proposal was made to Dr. Uprety for a staff seminar on phonology, which I was then invited to teach. Interestingly, the time and place of the seminar was changed after each lecture to make sure that only staff (and not students) would be able to attend.

On the $6^{\text {th }}$ of May, 1969, Ballabh Mani Dahal asked me to be the guide for his Ph.D. program. On the $14^{\text {th }}$ of July, 1970, Dahal left for a study program at Deccan College in Poona with a letter of reference I had written for him -- certainly a solid indication of his interest in linguistics, and I continued to be privileged to make contributions to Dahal's program in the form of comments on his papers, his thesis and his dissertation. On the $20^{\text {th }}$ of June, 1974, Dahal brought me a copy of his dissertation. In 1984, Dahal was elected President of the Linguistic Society of Nepal.

On the $27^{\text {th }}$ of April 1971, I met Tej Ratna Kansakar and showed him much of what we had been doing. This marked the beginning of a long series of mutually helpful sessions, initially on phonology. Our interaction over the years has continued to be mutually helpful, especially for me as I moved more deeply into the study of Newar - where I became the consultee and Kansakar, the consultant. Not only did Kansakar go on, in 1980, to earn his Ph.D. in linguistics, he was elected President of the Linguistic Society of Nepal in 1997.

Other indications of interest in minority languages came from scholars like Kamal Prakash Malla, who went abroad for language-related studies and returned to make many outstanding contributions to the study of Nepal Bhasa (Newar). I have learned much from him over the years. Not only did Malla earn his Ph.D. in linguistics, in 1979 he became the first person to be elected as President of the Linguistic Society of Nepal.

At some point in the 1970's Tribhuvan University's Institute of Nepal and Asian Studies (INAS) asked SIL to conduct some courses in linguistics. It was in such a course that I met Nirmal Man Tuladhar. Professor Tuladhar has gone on to make significant contributions in a number of areas. He has served as an editor of Nepalese Linguistics in 1980, and as chief editor in 1991. In 1992 he was elected President of the Linguistic Society of Nepal. In the mid-'90's he was Member-Secretary of the task force for the establishment of the Central Department of Linguistics of which Professor Bandhu was Chair. $\mathrm{He}$ is currently the Chairman of the Social Science Baha, an organization that promotes research in the social sciences in Nepal. (See $<$ www.soscbaha.org $>$.)

Professor Yogendra P. Yadava is also one who went abroad for advanced studies, earning the Ph.D. at EFLU in Hyderabad. We have benefitted greatly from Yadava's contributions over the years since then. He was the one who wrote the classic full-page article in The Rising Nepal for August 17, 1996, entitled "TU Faculty of Linguistics, A dream come true!" announcing the establishment of The Central Department of Linguistics. Yadava was elected President of the Linguistic Society of Nepal in 2000, and again in 2002. He has also been Head of The Central Department of Linguistics for a number of years. (See $<$ https://cdltu.edu.np/ $>$ ).

3. The Pike Workshop on Tone and Segmentals. (June 9-August 13, 1969)

Ken and Evie Pike arrived in Kathmandu on the $9^{\text {th }}$ of June, 1969, and worked on the analysis of segmentals and tone with the SIL teams studying Gurung, Tamang, Thakali, Sunuwar, Chepang, Sherpa and Newar. This workshop also gave local scholars an opportunity to witness such a workshop and to meet an important figure in the field of linguistics. On the $23^{\text {rd }}$ of December 1970 , 
C. M. Bandhu showed us his paper, Sinjali

Phonemic Summary. For us it was a very nice sequel to the Pike workshop, demonstrating his interest in phonology.

The Pikes left on the $13^{\text {th }}$ of August after a farewell from Dr. Uprety. The papers from this workshop were published in four parts as Hale and Pike, eds. 1970, "Tone systems of TibetoBurman languages of Nepal”, Occasional Papers of the Wolfenden Society on Tibeto-Burman Linguistics, vol. III.

By this time a fair bit of evidence had been provided as to the competence of SIL scholars and their serious intent to document the languages spoken in Nepal had been provided.

\section{A Glimpse of the Bigger Picture.}

After reading a preliminary draft of this account, our director, Kwang-Ju Cho, commented that he had a very good relationship with one of those who had been much involved in the early linguistic scene in Nepal, and was disappointed that I had not even mentioned him.

This was Professor Novel Kishore Rai, who had not only been Nepal's ambassador to Germany from 1995 to 2000, but who, in the process of completing his studies for the Ph.D. in the linguistics wrote a dissertation entitled, 'A Descriptive Study of Bantawa.' In 2006 he served as Chief Editor of Nepalese Linguistics. (See $<$ http://ecs.com.np./features/a-noble-lifeprofessor-novel-kishore-rai $>$.)

This is just one glimpse of the larger picture of the development of linguistic studies in Nepal that would be essential in a more definitive account. There are many others like this with whom we had only limited interaction in the early years, but who have made outstanding contributions who should be mentioned in such a review.

29 June 2019 